\title{
Vertical pit-mounds distribution of uprooted Norway spruce (Picea abies L.): field evidence in the upper mountain belt
}

\author{
Pawel Zadrozny ${ }^{(1)}$, \\ Wiktor Halecki ${ }^{(2-3)}$ \\ Michat Gąsiorek ${ }^{(1)}$,' \\ Paweł Nicia ${ }^{(1)}$, \\ Tomasz Lamorski ${ }^{(4)}$
}

\begin{abstract}
Tree uprooting causes significant changes in forest habitat functioning and soil formation. In this paper soil uplifted by tree throws was compared among $\mathbf{1 5}$ study plots from heterogeneous Norway spruce stands of the upper mountain belt in southern Poland. Pit-mound microtopography parameters such as length, width, depth of tree-throw pits, height of the root plate, and height of mineral and organic mounds, were measured at each uprooting site. Sites were grouped in 3 age groups based on the time elapsed since uprooting. Results showed significant differences between the studied parameters among age groups. Differences were most pronounced in mean pit depth $(0.52,0.65$ and $0.95 \mathrm{~m}$ for 5 -year, 3-year, and 1 -year-old pits, respectively). No significant interaction between age group and root plate height was detected by ANOVA. Regression analysis showed that pit depth decreases as root plate height increases. Redundancy analysis using pit-mound parameters as dependent variables revealed that root plate height along with slope steepness are good predictors of the volume of dislocated soil at tree-throw sites. Overall, our results suggest that the erosion expected at uprooting sites in mountain Norway spruce stands could be conveniently estimated by measuring their root plates. This may help estimate the impact of windthrow on soil microtopography and quantify its effects on soil disturbance in Norway spruce stands of the upper mountain belt.
\end{abstract}

Keywords: Bioturbation, Mountain Landscapes, Microtopography, Soil Disturbance, Tree Uprooting

\begin{abstract}
Introduction
Tree uprooting in mountain forest may provoke a severe and pervasive alteration of soil profile (Schaetzl et al. 1989, Schaetzl 1990, Samonil et al. 2010b) and habitat structure as well (Putz 1983, Grodzki \& Starzyk 2004, Pawlik 2012). Uprooted trees reallocate soil, biomass, carbon and nutrients (Stephens 1956, Norman et al. 1995, Clinton \& Baker 2000, Ulanova 2000, Phillips et al. 2008, Lenart et al. 2010). For instance, in Norway Spruce (Picea abies L.), which is among the tree species most sensitive to mechanical erosion, tree throw may increase mineral weathering processes (Zachara 2006, Simon et al. 2011).
\end{abstract}

Such bioturbation is likely to be an important long-term factor in forest ecology and should be incorporated into long-term ecology research on forest stands (Clinton \& Baker 2000, Phillips 2007). The variation of biogeochemical parameters following uprooting events can affect soil formation and vegetational succession of these microhabitats (Beatty \& Stone 1986). Further, climate change is likely to increase the occurrence of windthrow and uprooting events in the future (Emanuel 2005).

The aim of the study was to investigate on the microtopography and soil quality parameters of exposed pit-mounds of uprooted trees in old-growth stands of Nor-

$\square$ (1) Department of Soil Science and Soil Protection, University of Agriculture in Krakow, Al. Mickiewicza 21, 31-120 Kraków (Poland); (2) Department of Land Reclamation and Environmental Development, University of Agriculture in Krakow, Al. Mickiewicza 24/28, 30-059, Kraków (Poland); (3) Department of Biometry and Forest Productivity, Faculty of Forestry, University of Agriculture in Krakow, Al. 29 Listopada 46, 31-425 Krakow (Poland); (4) Babia Góra National Park, 34-223 Zawoja 1403 (Poland)

@ Wiktor Halecki (wiktor@mailmix.pl)

Received: Dec 19, 2015 - First Accepted: Mar 06, 2017 - Final Acceptance: Sept 1, 2017

Citation: Zadrozny P, Halecki W, Gasiorek M, Nicia P, Lamorski T (2017). Vertical pit-mounds distribution of uprooted Norway spruce (Picea abies L.): field evidence in the upper mountain belt. iForest 10: 783-787. - doi: 10.3832/ifor1959-010 [online 2017-09-02]

way spruce in Poland. To this aim, the following questions were posed: (1) how the vertical stratification of pit-mounds affect the overall topography of hilltops throughout the landscape? (2) how episodes that cause soil dislocation are best characterised? (3) how the root plate height might be used to study soil disturbances in the mountain area? (4) How pit-mounds affect soil rejuvenation at the forest stand level across a range of sites, and how this effect can be characterised?

\section{Materials and methods}

\section{Study site}

Fieldwork was carried out in forest lots located in the Babia Góra National Park, southern Poland (Fig. 1), where strong local winds caused a number of uprooting events in November 2004. Thereafter, a long-term ecological study was performed in several microhabitats where the majorpart of natural mound formation was due to weathering processes. We selected a 0.7 ha study area in the upper mountain belt, with elevation ranging from 1135 to $1198 \mathrm{~m}$ a.s.l. Slope steepness varied from $10^{\circ}$ to $40^{\circ}$. Soils are generally Skeletic Podzols, Dystric Skeletic Cambisols and Dystric Skeletic Regosols (IUSS Working Group 2015) that developed from weathered Magura formation sandstone. Forest stands of the upper mountain belt were dominated by 


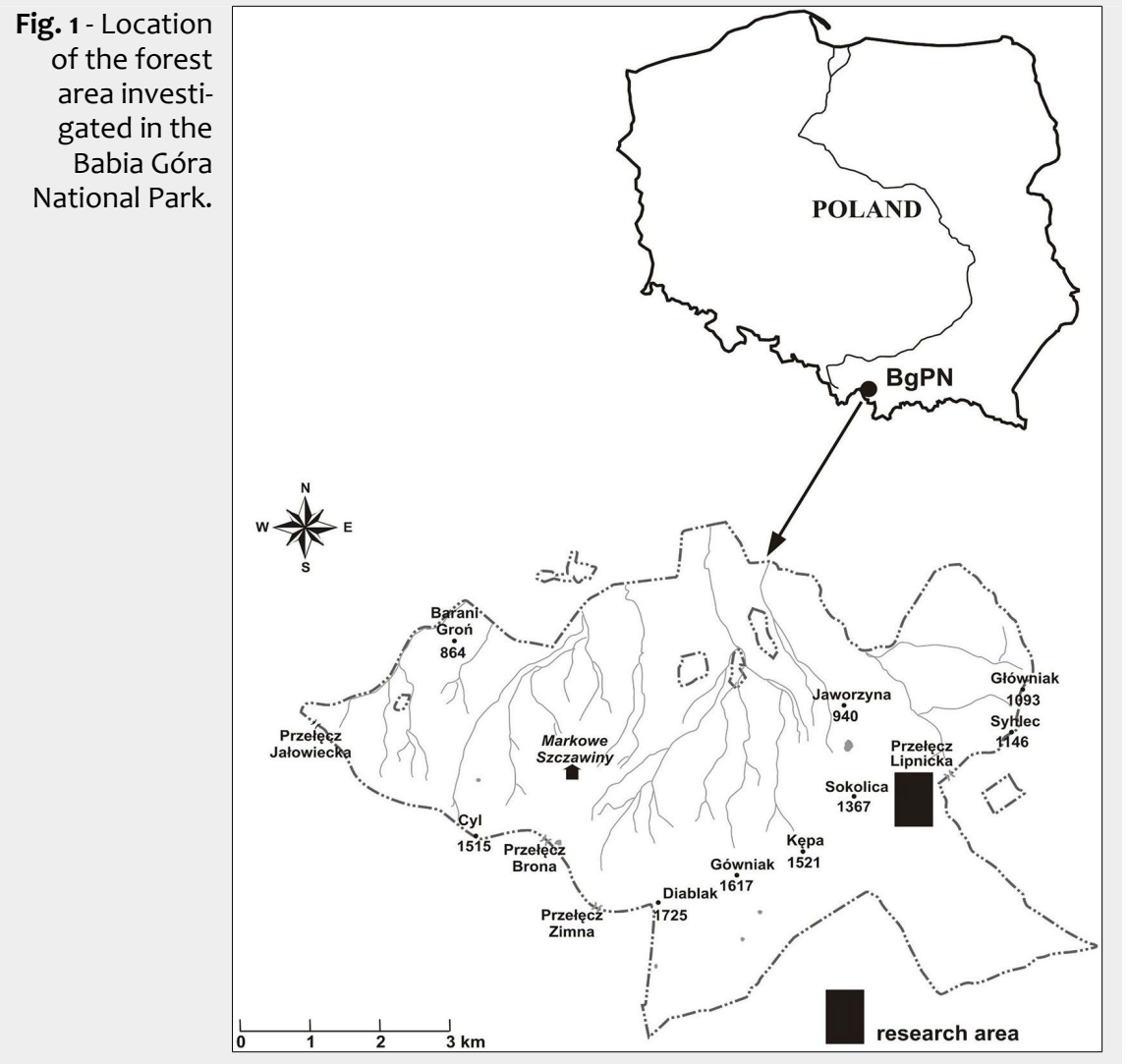

Norway spruce, showing the following average stand characteristics: 110 year-old, diameter (dbh) $33 \mathrm{~cm}, 30 \mathrm{~m}$ in height and $575 \mathrm{~m}^{3} \mathrm{ha}^{-1}$ of volume (Forest Inventory 2010). Plant communities were classified as Plagiothecio-Piceetum (tatricum) association with Vaccinium myrtillus and Athyrium distentifolium undergrowth (Parusel et al. 2004).

\section{Sampling design and data collection}

Five uprooted trees from each of 15 different study plots were selected all over the study area, totaling 75 uprooting sites. The selected sites were grouped in three age classes based on the time elapsed since the occurrence of tree uprooting (1, 3 , or 5 years). This allowed to compare the changes in pit-mound microtopography over time.

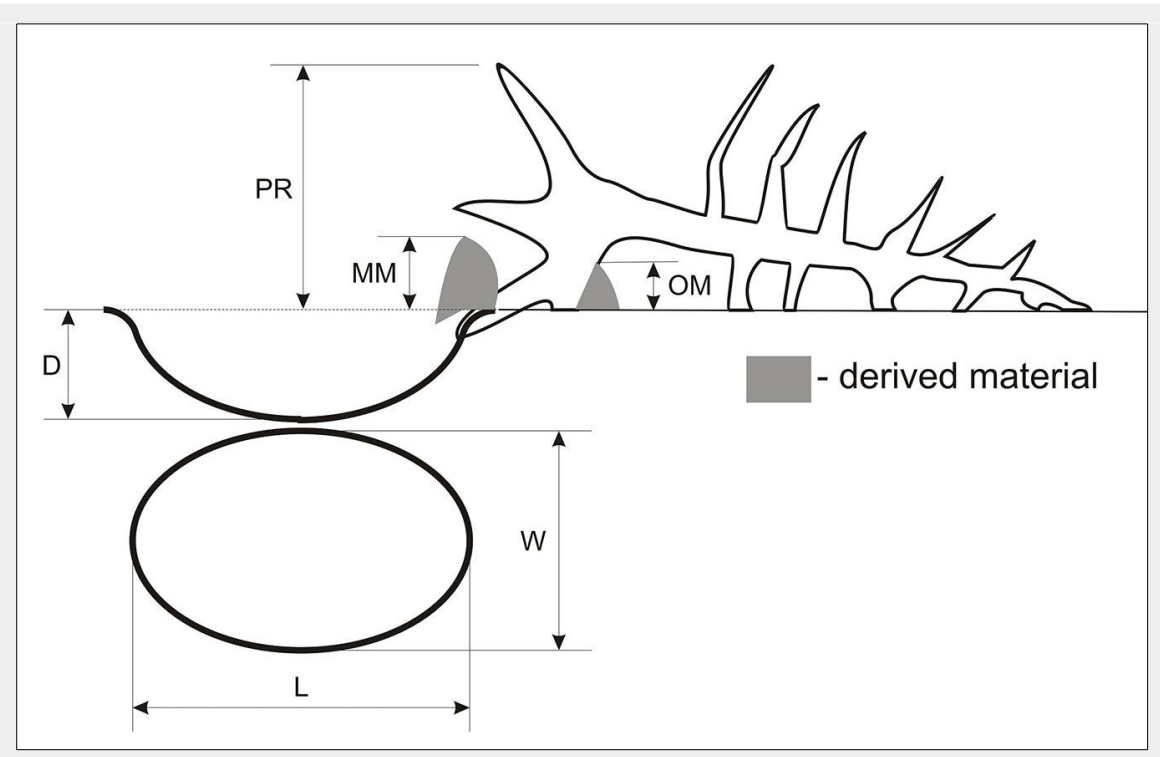

Fig. 2 - Schematic representation of the pit-mound microtopographic parameters measured at each uprooting site. (L): tree-throw pit length; (W): pit width; (D): pit depth; (PR): root plate height; (MM): mineral mound height; (OM): organic mound height.
The geometric parameters of pit-mounds micromorphology were evaluated according to Gabet et al. (2003) and Samonil et al. (2010a). For each pit-mound the following parameters were measured: length (L), width (W), depth (D) of the tree-throw pits; height of the plate root (PR); height of the mineral mound ( $M M$, the soil mineral material derived from the root plate); height of the organic mound (OM, the root plate-derived organic material - Fig. 2). The difference between the mineral (MM) and the organic (OM) mounds was taken as the thickness of the soil surface horizon (predominantly umbric epipedon in the study area - IUSS Working Group 2015). Moreover, the slope of each pit (which is considered a key erosion factor) was measured to assess the variation in microhabitat patterns through time. All the pit-mound variables were measured to investigate the susceptibility to mechanical erosion at the uprooting site.

\section{Statistical analysis}

To explore the relationships between the erosion factors of hilltops and the soil disturbance factors of the pit-mounds, redundancy analysis (RDA) was performed using the software CANOCO for Windows ${ }^{\circledR}$ v. 4.5 (Ter Braak \& Smilauer 2002). The predictor matrix was composed of 6 variables (pit length, pit width, pit depth, root plate height, $M M$ height and $O M$ height) for each of the 75 uprooting sites. The dependent variables were organized in a single matrix of 4 variables (pit depth, root plate height, slope steepness and volume of dislocated soil) for each of the 75 microsites. Resamples of residual data was performed to retain the structure of the interpolation. All variables were tested for normal distribution by applying the Shapiro-Wilk's test $(\alpha=0.05)$, and the homogeneity of variance among groups was verified by the Levene's test $(\alpha=0.05)$. Moreover, to assess the contribution of each variable to the overall correlation a non-parametric comparison for all pairs was conducted using the Steel-Dwaas test implemented in the $J M P^{\circledast}$ software package $\left(S A S^{\oplus}\right.$ ver. 11.04, Cary, NC, USA) with $\alpha=0.01$. Furthermore, the relationship between root plate height and depth was explored through linear regression analysis.

ANOVA was applied to test for differences in pit-mound characteristics among different sites and age groups (i.e., elapsed time since uprooting). Data were analysed using the $\mathrm{PaSt}^{\circledast}$ software (Paleontological Statistics, ver. 3.0). Statistical differences were reported significant at $\mathrm{P}<0.05$.

\section{Results}

\section{Pit-mound parameters}

Results showed a general trend of decrease in root plate height (PR) over time (Tab. 1). On average, the height of root plate decreased by $0.37 \mathrm{~m}$ between 1-yearold and 3-year-old pit-mounds, and by 0.16 
$\mathrm{m}$ between 3-year and 5-year old pitmounds. In addition, a remarkable difference was found in both length and depth of the pit between 1-year and 3-year-old pitmounds, where the average length of the pit decreased by $0.48 \mathrm{~m}$ and the depth by $0.30 \mathrm{~m}$. Differences between the 3-year and 5-year-old pit-mounds appeared not as much large $(0.06 \mathrm{~m}$ and $0.13 \mathrm{~m}$ for length and depth, respectively). The width of the pit showed a comparable trend; the average width between 1-year-old and 3-yearold pit-mounds decreased by $0.55 \mathrm{~m}$, and decreased an average of $0.40 \mathrm{~m}$ between the 3-and 5-year-old pit-mounds.

A decrease of mineral mound (MM) height and a slight increase of organic mound (OM) height was also observed. On average, the height of the mineral mound in 3-year-old pit-mounds was $0.29 \mathrm{~m}$ lower than in 1-year-old pit mounds; however, this was very similar to the 5 -year-old pit mounds. The height of the organic mounds in 1-year and 3-year-old pit-mounds was similar, whereas in the five-year-old pitmounds it was slightly higher, by $0.06 \mathrm{~m}$ (Tab. 1).

ANOVA revealed no significant differences between age groups and interaction between age and root plate height $(\mathrm{P}>$ 0.05). However, statistically significant differences in microtopographic variables among pit-mounds were observed (Tab. 2).

\section{Soil dislocation}

Linear regression analysis showed a significant negative relationship between pit depth and root plate height $\left(R^{2}=0.64-\right.$ Fig. 3), that is, shallower pits were associated with higher root plates.

Results of the RDA analysis are summarized in Fig. 4. The first axis accounted for $32 \%$ of the total variance, while the second for $36.5 \%$. Correlation between site topographic features and microtopography parameters of pit-mounds revealed that both pit depth and root plate height were negatively associated with slope steepness. Interestingly, the depth of the uprooted pit was negatively correlated with both axes.

The results of the Steel-Dwaas test carried out revealed a significant $(P<0.01)$ erosion of surface horizons in terms of volume of eroded soil, particularly on steep slopes (Fig. 4).

\section{Discussion}

Tree uprooting has a significant impact on pedogenetic processes, both rejuvenating the soils and hampering its formation (Samonil et al. 2016). Indeed, uprooted trees may shape forest habitats in the upper mountain belt, where windthrows often largely affect the land cover.

In this study, no significant differences were found among age groups of treeuprooting sites $(P>0.05)$, though pitmound differences were significant after ANOVA ( $p<0.05-$ Tab. 2 ). Previous studies have reported that the elapsed time since the uprooting event drives the dynamic of
Tab. 1 - Mean values ( \pm standard error) of the parameters measured on the studied pit-mounds. Different letters in each row indicate significant differences between age classes after Tukey's test $(P<0.05)$.

\begin{tabular}{lccc}
\hline Pit-Mound & \multicolumn{3}{c}{ Pit-mound age class } \\
\cline { 2 - 4 } Parameters & 1-year-old & 3-year-old & 5-year-old \\
\hline Pit length $(\mathrm{m})$ & $2.74 \pm 0.29^{\mathrm{a}}$ & $2.26 \pm 0.05^{\mathrm{b}}$ & $2.18 \pm 0.09^{\mathrm{b}}$ \\
Pit width $(\mathrm{m})$ & $4.23 \pm 0.24^{\mathrm{a}}$ & $3.68 \pm 0.12^{\mathrm{b}}$ & $3.28 \pm 0.28^{\mathrm{b}}$ \\
Pit depth (m) & $0.95 \pm 0.09^{\mathrm{a}}$ & $0.65 \pm 0.02^{\mathrm{b}}$ & $0.52 \pm 0.12^{\mathrm{b}}$ \\
\hline Root plate height $(\mathrm{m})$ & $2.35 \pm 0.15^{\mathrm{b}}$ & $1.98 \pm 0.34^{\mathrm{b}}$ & $1.82 \pm 0.45^{\mathrm{b}}$ \\
\hline MM height $(\mathrm{m})$ & $0.71 \pm 0.22^{\mathrm{b}}$ & $0.42 \pm 0.11^{\mathrm{b}}$ & $0.44 \pm 0.19^{\mathrm{b}}$ \\
\hline OM height $(\mathrm{m})$ & $0.33 \pm 0.09^{\mathrm{b}}$ & $0.32 \pm 0.07^{\mathrm{b}}$ & $0.38 \pm 0.08^{\mathrm{b}}$ \\
\hline
\end{tabular}

Tab. 2 - Results of the ANOVA using pit-mounds microtopography parameters with their combined root plate parameters. F-values and P-values for pit-mound parameters with effect (age): 1-year, 3-year and 5-year-old. (df): degrees of freedom; (ns): not significant ( $P>0.05)$.

\begin{tabular}{lcccc}
\hline Factors & Sum of squares & df & F & P-value \\
\hline Pit-mound & 10.63 & 14 & 3.29 & $<0.05$ \\
Age class & 131.76 & 75 & 114.31 & ns \\
Root plate height $\times$ age class & 158.52 & 70 & 1.05 & ns \\
Error & 16.52 & 89 & - & - \\
\hline
\end{tabular}
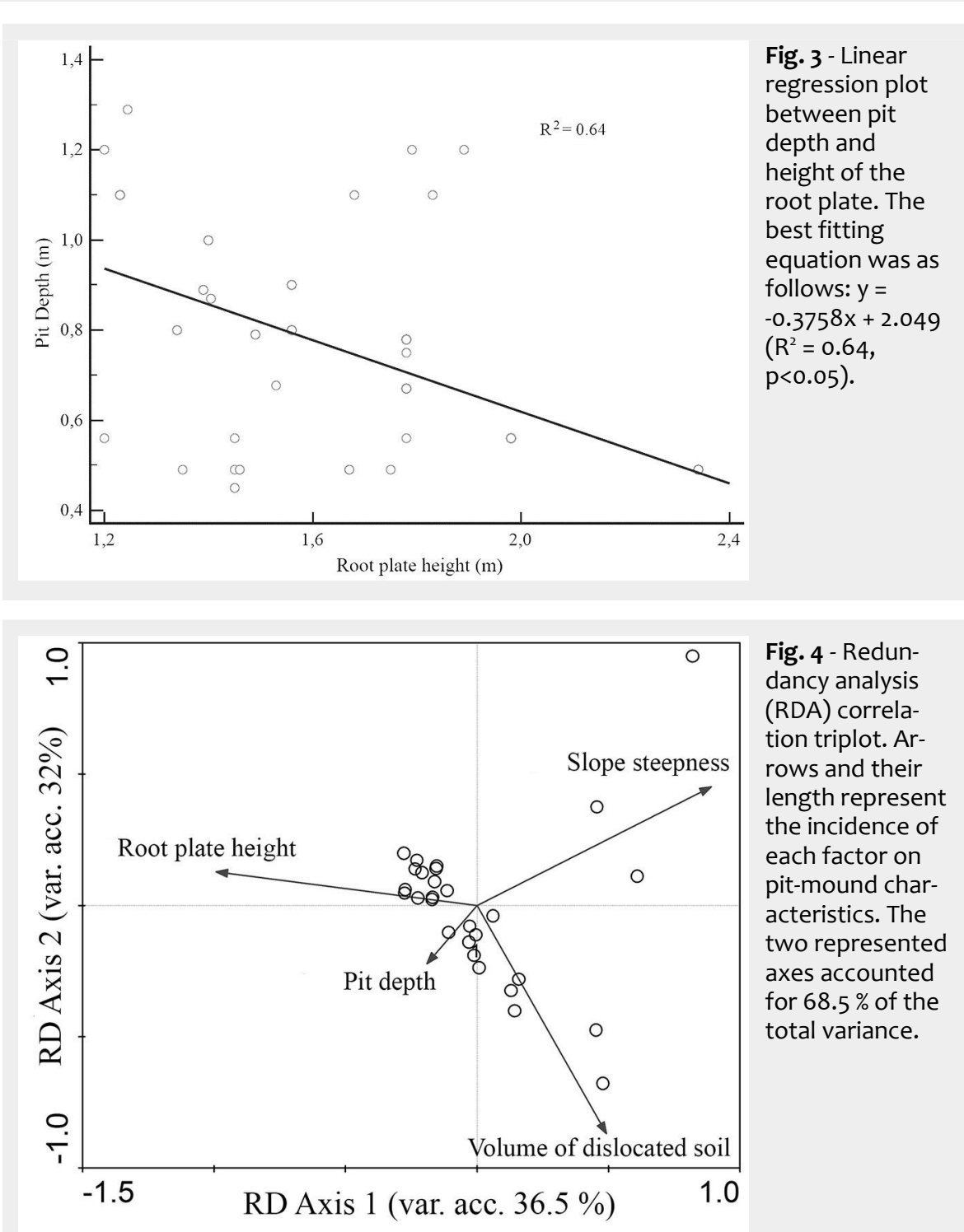

Fig. 4 - Redundancy analysis (RDA) correlation triplot. Arrows and their length represent the incidence of each factor on pit-mound characteristics. The two represented axes accounted for $68.5 \%$ of the total variance. 
pit-mound microtopography (Samonil et al. 2010b). However, this tendency was not observed in our study.

Tree uprooting is an important factor affecting the regeneration in Norway spruce stands of the upper mountan belt, providing new microhabitats suitable for colonization of forest tree species (Samonil et al. 2016). Indeed, we observed the presence of spruce saplings in surveyed plots, especially on bare soil microsites. Further, the presence of the root plate of uprooted trees in Norway Spruce stands may provide favorable conditions to new recruits in terms of wind protection. On the other hand, such new habitats are exposed to the ground vegetation, which is no more limited by the canopy cover, thus allowing the survival of a specific vegetation (Holeksa 1998). Currently, most of the plant species observed in the studied plots are typical of the Plagiothecio-Piceetum (tatricum) association. However, at lower altitudes more complex situations can be found due to the existence of erosion processes originating from neighbouring hills (Clarke \& Burbank 2010, Finke et al. 2013).

We initially assumed that all studied plots were exposed to erosion caused by the abundant rainfall typical of mountain climate. The results of the redundancy analysis confirmed such assumption, revealing that slope steepness has the largest impact on soil dislocation at the studied uprooting sites (Fig. 4). Soil dislocation is affected by a variety of microsite conditions, primarily the amount of formed soil and the surface horizons, but also the microclimatic conditions (Osterkamp et al. 2011, Simon et al. 2011). Displacement of soil causes incipient sediment aggregation and increases the rate of erosion (Mudd \& Furbish 2007, Heimsath et al. 2009, Norton \& Blanckenburg 2010, Egli et al. 2013).

In this study, tree-throw pit depth decreased as the width of root plate increased (Fig. 3). Consequently, the volume of uplifted soil is also decreasing with root plate width, as pit volume is highly correlated with its depth. This was assumed to be caused by backward rotation of the uprooting tree. Based on our results, soil pit-mound parameters and soil thickness are appropriate predictors of soil dislocation by the uprooted tree, in agreement with previous studies (Schaetzl et al. 1989, Gabet et al. 2003, Roering 2008, Gabet \& Mudd 2010, Roering et al. 2010).

Our results suggest that the effect of uprooted trees on soil dislocation in mountain Norway spruce stands could be conveniently estimated by measuring their root plates. This may help estimate the impact of windthrow on soil microtopography and quantify its effects on soil disturbance in hill slopes of mountainous areas.

\section{Conclusions}

Pit-mound microtopography is an appropriate indicator of soil formation in Norway spruce stands in the upper mountain belt.
Length, width and depth of pits and height of root plates decreased with increasing the elapsed time since uprooting. A clear reduction in height of the mineral mounds occurred only between 1-year and 3-yearold pit-mounds, whereas the height of organic mounds was similar in all age groups. In general, the effect of erosion in mountain Norway spruce stands depends on the amount of uplifted soil during the uprooting event. Our results suggest that the erosion expected at uprooting sites in Norway spruce stands of the upper mountain belt can be estimated by using the microtopographic parameters of the pit-mounds and the root plate height. However, further studies are needed to quantify the effects of the ground vegetation colonizing the uprooting sites on the erosion process in hilltop Norway spruce stands.

\section{Acknowledgments}

This research was financed by the Ministry of Science and Higher Education of the Republic of (Poland grant no. N N305 106534) in years 2008-2009. The authors would like to express their gratitude to the Authorities of the Babia Gora National Park for the help and supply of spatially referenced forest structure in this study.

\section{References}

Beatty SW, Stone EL (1986). The variety of soil microsites created by tree falls. Canadian Journal Forest Research 16: 539-548. - doi: 10.1139/ x86-094

Clarke BA, Burbank DW (2010). Bedrock fracturing, threshold hillslopes, and limits to the magnitude of bedrock landslides. Earth and Planetary Science Letters 297: 577-586. - doi: 10.1016/ j.epsl.2010.07.011

Clinton BD, Baker CR (2000). Catastrophic windthrow in the southern Appalachians: characteristics of pits and mounds and initial vegetation responses. Forest Ecology and Management 126: 51-60. - doi: 10.1016/S0378-1127(99)00082-1 Egli M, Dahms D, Norton K (2013). Soil formation rates on silicate parent material in alpine environments: different approaches-different results? Geoderma 213: 320-333. - doi: 10.1016/j. geoderma.2013.08.016

Emanuel K (2005). Increasing destructiveness of tropical cyclones over the past 30 years. Nature 436: 686-688. - doi: 10.1038/nature03906

inke PA, Vanwalleghem E, Poesen J, Deckers J (2013). Estimating the effect of tree uprooting on variation of soil horizon depth by confronting pedogenetic simulations to measurements in a Belgian loess area. Journal of Geophysical Research: Earth Surface 118: 2124-2139. doi: 10.1002/jgrf.20153

Forest Inventory (2010). Data base of the Babia Góra National Park. In: "Protection of forest and non-forest ecosystems of the Babia Góra National Park". Taxus, Warsaw, Poland, pp. 1360.

Gabet EJ, Mudd SM (2010). Bedrock erosion by root fracture and tree throw: a coupled biogeomorphic model to explore the humped soil production function and the persistence of hillslope soils. Journal of Geophysical Research 115
(F4): 35. - doi: 10.1029/2009JF001526 Gabet JE, Reichman JO, Seabloom WE (2003). The effects of bioturbation on soil processes and sediment transport. Annual Review of Earth and Planetary Science 31: 249-273. - doi: 10.1146/annurev.earth.31.100901.141314 Grodzki W, Starzyk JR (2004). Windthrowns in selected national parks in the Carpathians and related research needs concerning forest protection. Lesne Prace Badawcze 3: 119-124. [in Polish]

Heimsath AM, Fink D, Hancock GR (2009). The "humped" soil production function: eroding Arnhem Land, Australia. Earth Surface Processes and Landforms 34: 1674-1684. - doi: 10.1002/esp.1859

Holeksa J (1998). Breakdown of tree stand and spruce regeneration versus structure and dynamics of a Carpathian subalpine spruce forest. Monographiae Botanicae 82: 1-209. [in Polish] doi: $10.5586 / \mathrm{mb} .1998 .001$

IUSS Working Group (2015). World reference base for soil resources 2014 (update 2015). International soil classification system for naming soils and creating legends for soil maps. World Soil Resources Reports No. 106, FAO, Rome, Italy, pp. 182.

Lenart MT, Falk DA, Scatena FN, Osterkamp WR (2010). Estimating soil turnover rate from tree uprooting during hurricanes in Puerto Rico. Forest Ecology and Management 259: 10761084. - doi: 10.1016/j.foreco.2009.12.014

Mudd SM, Furbish DJ (2007). Responses of soilmantled hillslopes to transient channel incision rates. Journal of Geophysical Research 112 (F3): 29. - doi: 10.1029/2006JFoo0516

Norman SA, Schaetzl RJ, Small TW (1995). Effects of slope angle on mass movement by tree uprooting. Geomorphology 14: 19-27. - doi: 10.1016/0169-555X(95)00016-X

Norton PK, Blanckenburg F (2010). Silicate weathering of soil-mantled slopes in an active Alpine landscape. Geochimica et Cosmochimica Acta 74: 5243-5258. - doi: 10.1016/j.gca.2010.06. 019

Osterkamp WR, Hupp RC, Stofell M (2011). The interactions between vegetation and erosion: new directions for research at the interface of ecology and geomorphology. Earth Surface Processes and Landforms 37: 23-36. - doi: 10.1002/esp. 2173

Parusel J, Kasprowicz M, Holeksa J (2004). Forests and brushwood communities in the Babiogórski National Park. In: "The nature of the Babiogórski National Park monograph" (Woloszyn BW, Jaworski A, Szwagrzyk J eds). Babiogórski National Park and Nature Conservation Committee, Polish Academy of Sciences, Krakow, Poland, pp. 429-475. [in Polish]

Pawlik L (2012). Disturbance of hillslope surfaces due to the tree uprooting process in the Sudetes Mts., SW Poland. Landform Analysis 20: 79-94. [in Polish]

Phillips JD (2007). Soil system modeling and generation of field hypotheses. Geoderma 145: 419425. - doi: 10.1016/j.geoderma.2007.07.001

Phillips JD, Marion DA, Turkington AV (2008). Pedologic and geomorphic impacts of a tornado blowdown event in a mixed pine-hardwood forest. Catena 75: 278-287. - doi: 10.1016/j.cate na.2008.07.004 
Putz FE (1983). Treefall pits and mounds, buried seeds and the importance of soil disturbance to pionier trees on Barro Colorado Island, Panama. Ecology 64: 1069-1074. - doi: 10.2307/1937 815

Roering JJ (2008). How well can hillslope evolution models "explain" topography? Simulating soil production and transport using high-resolution topographic data. Geological Society of America Bulletin 120: 1248-1262. - doi: 10.1130/ B26283.1

Roering JJ, Marshall J, Adam M, Booth MA, Mort $M$, Jin Q (2010). Evidence for biotic controls on topography and soil production. Earth and Planetary Science Letters 298: 183-190. - doi: 10.1016/j.epsl.2010.07.040

Schaetzl RJ (1990). Effects of treethrow microtopography on the characteristics and genesis of Spodosols, Michigan, USA. Catena 17: 111-126. - doi: 10.1016/0341-8162(90)90002-U

Schaetzl RJ, Johnson DL, Burns SF, Small TW (1989). Tree uprooting: review of terminology, process, and environmental implications. Canadian Journal Forest Resources 19: 1-11. - doi: 10.1139/x89-001

Simon A, Gratzer G, Sieghardt M (2011). The influence of windthrow microsites on tree regeneration and establishment in an old growth mountain forest. Forest Ecology and Management 262: 1289-1297. - doi: 10.1016/j.foreco.201 1.06.028

Stephens EP (1956). The uprooting of trees: a forest process. Soil Science Society of America Journal 20: 113-116. - doi: 10.2136/sssaj1956.0361 5995002000010029x

Samonil P, Král K, Hort L (2010a). The role of tree uprooting in soil formation: a critical literature review. Geoderma 157: 65-79. - doi: 10.1016/j. geoderma.2010.03.018

Samonil P, Tejnecky V, Borúvka L, Sebková B, Janík D, Sebek O (2010b). The role of tree uprooting in Cambisol development. Geoderma 159: 83-98. - doi: 10.1016/j.geoderma.2010.06. 020
Samonil P, Valtera $M$, Schaetzl RJ, Dušan A, Vašíčková I, Danek P, Janík D, Tejnecky V (2016). Impas of old, comparatively stable, treethrow microtopography on soils and forest dynamics in the northern hardwoods of Michigan, USA. Catena 140: 55-65. - doi: 10.1016/j.catena.2016. 01.006

Ter Braak CJF, Smilauer P (2002). CANOCO reference manual and CanoDraw for Windows user's guide: software for canonical community ordination (version 4.5). Microcomputer Power, Ithaca, NY, USA, pp. 500. [online] URL: http://library.wur.nl/WebQuery/wurpubs/wever 1341885

Ulanova NG (2000). The effects of windthrow on forests at different spatial scales: a review. Forest Ecology and Management 135: 155-167. - doi: 10.1016/S0378-1127(00)00307-8

Zachara T (2006). Damage to forests caused by snow and wind and the ways of counteracting it. Sylwan 10: 56-64. [in Polish] 